\title{
VALIDATION OF A DEVELOPED ANALYTICAL METHOD FOR DETERMINATION OF NATEGLINIDE AND METFORMIN HCL IN PURE AND PHARMACEUTICAL DOSAGE FORM BY REVERSED-PHASE HIGH-PERFORMANCE LIQUID CHROMATOGRAPHY AND ITS DEGRADATION STUDIES
}

\author{
K.MD ISMAIL ${ }^{1}$, A LAKSHMANA RAO ${ }^{2 *}$ \\ ${ }^{1}$ Department ofPharmaceutical Analysis, Nizam Institute of Pharmacy, Deshmukhi Village, Nalgonda, Telangana, India. ${ }^{2}$ Department of \\ Pharmaceutical Analysis, V.V. Institute of Pharmaceutical Sciences, Gudlavalleru, Krishna, Andhra Pradesh, India. Email: dralrao@gmail.com
}

Received: 30 August 2020, Revised and Accepted: 10 November 2020

\section{ABSTRACT}

Objective: The objective of the study was to develop a versatile analytical method and validate according to International Council for Harmonization guidelines for simultaneous estimation of nateglinide and metformin $\mathrm{HCl}$ by reversed-phase high-performance liquid chromatography (RP-HPLC) in active pharmaceutical ingredient and in tablet dosage form.

Methods: Analytes, metformin and nateglinide, are separated and eluted from stationary phase luna phenyl hexyl column $(150 \mathrm{~mm} \times 4.6 \mathrm{~mm}, 3.5 \mu \mathrm{m})$ (micrometer) using polar mobile phase composed of acetonitrile:1\% orthophosphoric acid 30:70 v/v, with flow rate of $1 \mathrm{ml} / \mathrm{min}$ for $8 \mathrm{~min}$ at ambient column temperature, at $221 \mathrm{~nm}$ (nanometer) detection. Acid, base, peroxide, thermal, and photolytic-induced degradation studies were performed on nateglinide and metformin.

Results: Through isocratic flow, both metformin and nateglinide are detected at retention times of $2.79 \mathrm{~min}$ and $5.13 \mathrm{~min}$, respectively, at $221 \mathrm{~nm}$. The linearity and range of analytical method for nateglinide and metformin were $0.61-9.15 \mu \mathrm{g} / \mathrm{ml}$ and $7.5-75.15 \mu \mathrm{g} / \mathrm{ml}$, respectively. The $\mathrm{R}^{2}$ value for nateglinide was 0.9998 and for metformin $\mathrm{HCl}$ was 0.9991 . The limit of detection and limit of quantification for nateglinide were $0.21 \mu \mathrm{g} / \mathrm{ml}$ and $0.63 \mu \mathrm{g} / \mathrm{ml}$ and for metformin were $4.8 \mu \mathrm{g} / \mathrm{ml}$ and $14.6 \mu \mathrm{g} / \mathrm{ml}$, respectively. The $\%$ relative standard deviation for method precision was found to be $0.22 \%$ and $0.64 \%$ for both nateglinide and metformin, respectively. The mean \%recovery for nateglinide and metformin was $99.88 \%$ and $99.21 \%$, respectively. The \%thermal degradation was identified as $17.7 \%$ and $17.5 \%$ for nateglinide and metformin, respectively.

Conclusion: The developed chromatographic (RP-HPLC) method was selective, specific, economic, precise, and accurate. Hence, it can be one of the preferred analytical methods of choice for the estimation of nateglinide and metformin by RP-HPLC in pure and in tablet dosage form.

Key words: Nateglinide, Metformin, Reversed-phase high-performance liquid chromatography, Isocratic, Acetonitrile.

(c) 2021 The Authors. Published by Innovare Academic Sciences Pvt Ltd. This is an open access article under the CC BY license (http://creativecommons.org/ licenses/by/4.0/) DOI: http://dx.doi.org/10.22159/ajpcr.2021v14i1.39530. Journal homepage: https://innovareacademics.in/journals/index.php/ajpcr

\section{INTRODUCTION}

Nateglinide is chemically 3-phenyl-2-[(4-propan-2-yl cyclohexane carbonyl) amino] propanoic acid (Fig. 1) with molecular formula $\mathrm{C}_{19} \mathrm{H}_{27} \mathrm{NO}_{3}$. It acts by blocking adenosine triphosphate sensitive potassium channels of beta cells of pancreas, causes membrane depolarization results in calcium influx and their by stimulation of insulin secretion. Metformin $\mathrm{HCl}$ is chemically $\mathrm{N}, \mathrm{N}$-Dimethyl imidodicarbonimidic diamide hydrochloride (Fig. 2) with molecular formula $\mathrm{C}_{4} \mathrm{H}_{11} \mathrm{~N}_{5} \cdot \mathrm{HCl}$. The main mechanism of metformin $\mathrm{HCl}$ was lowering glucose intestinal absorption, inhibition of hepatic glucose production, and improving glucose uptake and utilization [1-6].

It was found that very few articles are available in detailed literature survey on simultaneous estimation of nateglinide and metformin $\mathrm{HCl}$ by reversed-phase high-performance liquid chromatography (RP-HPLC) in pure and dosage form [7-9]. The resting literature was found on analytical and bioanalytical methods by HPLC, LCMS/MS, RP-LC, high-performance thin-layer chromatographic, and ultraviolet (UV) spectrophotometric estimations, in combination with glinides (nateglinide, repaglinide, and mitiglinide) and metformin $\mathrm{HCl}$ [10-21].

The comprehensive literature survey disclosed diverse analytical techniques of estimating nateglinide and metformin $\mathrm{HCl}$ in single and in combination with other drugs. The present study was taken up to develop a sensitive, accurate, precise, and simple method of analysis for the estimation of both drugs in combined dosage forms.

\section{METHODS}

Chemicals and reagents

The active pharmaceutical ingredients (APIs), nateglinide and metformin hydrochloride, were supplied as a gift sample by Care Labs, L.B Nagar, Hyderabad, and marketed formulation was purchased from the local market. HPLC grade orthophosphoric acid, acetonitrile, and water were of Merck grade. Waters autosampler RP-HPLC, e2695 pump, and 2998 photodiode array (PDA) detector with Empower2 software were employed in this method.

\section{Selection and preparation of mobile phase and diluent}

In RP-HPLC, pure API mixture containing nateglinide and metformin $\mathrm{HCl}$ at lower concentration levels were prepared, injected, and run with different solvent systems. Different combination of solvents using acetonitrile, triethylamine, and orthophosphoric acid at different compositions, flow rates, and ratios were tried to optimize the mobile phase. Finally from the trials, mobile phase and diluent (acetonitrile and $0.1 \%$ orthophosphoric acid in a ratio of $30: 70 \mathrm{v} / \mathrm{v}$ ) are selected since they were fulfilling the requirements and the results obtained were within the acceptable limits.

Preparation of standard stock solution

Powder analytes equivalent to $6 \mathrm{mg}$ and $50 \mathrm{mg}$ of nateglinide and metformin $\mathrm{HCl}$, respectively, were accurately weighed and transferred 


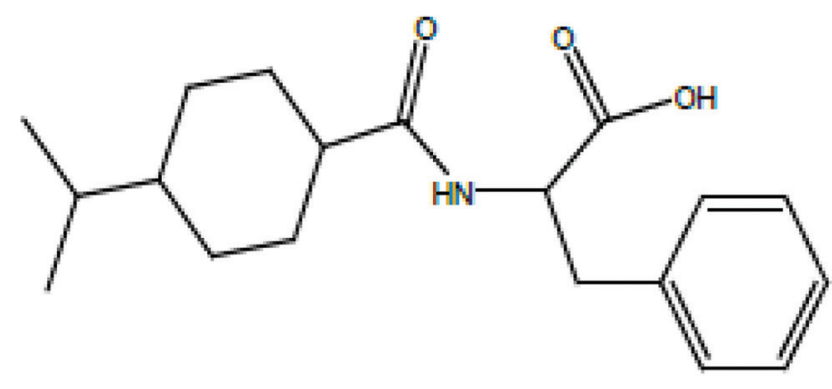

Fig. 1: Chemical structure of nateglinide

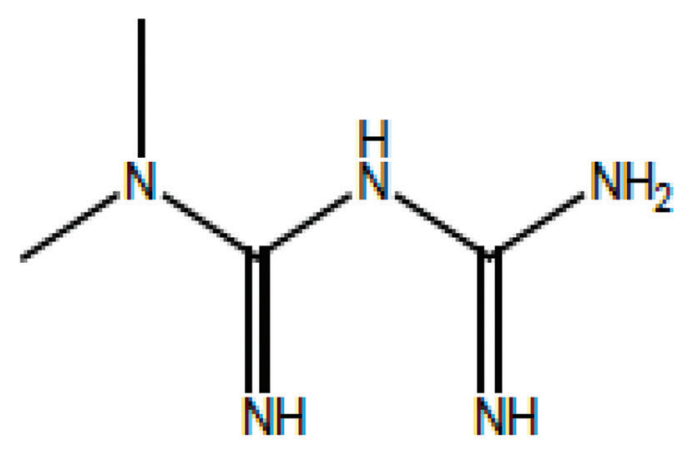

Fig. 2: Chemical structure of metformin $\mathrm{HCl}$

to calibrated $100 \mathrm{ml}$ volumetric flask, added $50 \mathrm{ml}$ of diluent, sonicated for $10 \mathrm{~min}$, and filled up to the mark with diluent.

\section{Preparation of working standard solution}

Five milliliters of standard stock solution were transferred into $50 \mathrm{ml}$ calibrated volumetric flask and filled up to the mark with the diluent.

\section{Selection of detection wavelength $\left(\lambda_{\max }\right)$ (maximum absorbance wavelength)}

Nateglinide $(6 \mu \mathrm{g} / \mathrm{ml})$ and metformin $\mathrm{HCl}(50 \mu \mathrm{g} / \mathrm{ml})$ solutions were prepared separately using diluent and scanned separately in Shimadzu 1800 UV-visible spectrophotometer at a range of $200-400 \mathrm{~nm}$.

\section{Optimized chromatographic conditions}

Many trials have been conducted to optimize all the chromatographic conditions required for simultaneous estimation of nateglinide and metformin $\mathrm{HCl}$. Finally, reverse phase $\mathrm{C} 18$ column, luna phenyl hexyl column $(150 \mathrm{~mm} \times 4.6 \mathrm{~mm}, 3.5 \mu)$, mobile phase containing acetonitrile: $0.1 \%$ orthophosphoric acid (30:70 v/v ratio), flow rate $1.0 \mathrm{ml} / \mathrm{min}$, run time $8 \mathrm{~min}$, injection volume $-10 \mu \mathrm{l}$, and a detection wavelength - $221 \mathrm{~nm}$ using a PDA detector are the best possible optimized chromatographic conditions which gave the best resolution, $\mathrm{s} / \mathrm{n}$ (signal to noise) ratio, peak tailing, and United States Pharmacopeia (USP) plate count for the present estimation.

\section{Preparation of calibration curve solutions}

Eight standard solutions were prepared to construct calibration curve. Different concentrations of nateglinide $(0.61 \mu \mathrm{g} / \mathrm{ml}-9.15 \mu \mathrm{g} / \mathrm{ml})$ and metformin $\mathrm{HCl}(5.01 \mu \mathrm{g} / \mathrm{ml}-75.15 \mu \mathrm{g} / \mathrm{ml})$ were prepared using diluent and injected into stabilized RP-HPLC system which was in already mentioned optimized chromatographic conditions. The peak areas (on y-axis) obtained from respective concentrations (on x-axis) were taken into consideration to plot a calibration curve. The linearity, range, intercept, slope, and $\mathrm{r}^{2}$ were calculated from calibration curve.

Analysis of nateglinide and metformin $\mathrm{HCl}$ from marketed tablets From 20 tablets weight, average weight of each tablet was calculated. Triturated the tablets into fine powder and equivalent to $6 \mathrm{mg}$ of nateglinide and $50 \mathrm{mg}$ of metformin $\mathrm{HCl}$ of tablet powder was weighed and transferred to $100 \mathrm{ml}$ volumetric flask mixed with $70 \mathrm{ml}$ of diluent, sonicated for $30 \mathrm{~min}$, and filled up to the mark with the same. Filtered the resulting solution through $0.45 \mu \mathrm{m}$ filter paper and from the filtrate $5 \mathrm{ml}$ was transferred in $50 \mathrm{ml}$ of volumetric flask mixed and adjusted the volume to the mark with diluent and sonicated the final solution for $5 \mathrm{~min}$. From the prepared solution, $10 \mu \mathrm{l}$ replicates were injected into RP-HPLC chromatographic system. The peak areas obtained from chromatograms were tabulated for amount of nateglinide and metformin $\mathrm{HCl}$ present in each tablet.

\section{System suitability}

To ensure that the system was working perfectly and exploring the feasible results throughout the analysis, system suitability test was performed. To evaluate system suitability, six working standard solutions were injected and the parameters such as resolution (Rs), retention time (Rt), tailing factor (Tf), USP plate count $(\mathrm{N})$, and \%RSD of peak areas were calculated from the chromatograms of analytes of interest.

Validation of analytical method [22-25]

Selectivity and specificity

The developed method was said to be selective, when nateglinide and metformin $\mathrm{HCl}$ are completely separated from each other with fixed resolution and retention time at optimized chromatographic conditions. Selectivity of the recommended method was evaluated by repeated injections of working standard solutions.

The purpose of testing specificity was to identify the interference peaks from the impurities or from excipients of dosage form at the same retention times of compounds of interest at optimized chromatographic conditions. By injecting tablet extract, placebo blank, standard drug solutions, and mobile phase (blank) specificity of the method was evaluated.

\section{Accuracy}

According to the guidelines to estimate the accuracy of the method, triplicates of three different concentration levels of standard solutions $(50 \%, 100 \%$, and $150 \%)$ containing both nateglinide and metformin $\mathrm{HCl}$ were injected into RP-HPLC system. Before standard injections, a blank solution (mobile phase) was injected. From each chromatogram obtained, percentage of drug recovery, mean \% of drug recovery, and $\%$ RSD are calculated.

\section{Precision}

System precision

System precision or chromatographic system performance was estimated by injecting six replicate freshly prepared working standard solutions containing $6 \mu \mathrm{g} / \mathrm{ml}$ of nateglinide and $50 \mu \mathrm{g} / \mathrm{ml}$ of metformin $\mathrm{HCl}(100 \%$ test concentration) into HPLC system. The percentage relative standard deviation (\%RSD) was computed from the peak areas of nateglinide and metformin $\mathrm{HCl}$ chromatograms.

\section{Method precision}

To determine method precision of proposed analytical method, six replicates of working standard solutions and six replicates of sample solutions containing $6 \mu \mathrm{g} / \mathrm{ml}$ of nateglinide and $50 \mu \mathrm{g} / \mathrm{ml}$ of metformin $\mathrm{HCl}$ was injected into HPLC system without changing the optimized chromatographic conditions. From the peak areas obtained, calculated the presence of percentage of analytes in each injection. The \%RSD for mean peak areas and assay was computed.

\section{Intermediate precision}

Six samples of same batch were analyzed to calculate the intermediate precision of the proposed analytical method by different analyst on different day on different instrument. The \%RSD for mean peak areas and assay was computed.

\section{Robustness}

To ensure the robustness of the proposed analytical method, the flow rate was adjusted to $0.8 \mathrm{ml} / \mathrm{min}, 1.2 \mathrm{ml} / \mathrm{min}$ and organic composition of 
mobile phase was changed to $\pm 10 \%$ and notified the changes occurred in the chromatograms after injecting the working standard solutions and sample solutions containing nateglinide and metformin $\mathrm{HCl}$.

Limit of detection (LOD) and limit of quantification (LOQ)

LOD and LOQ are defined as the lowest concentrations to detect and to quantify the analyte(s) respectively. To estimate LOD and LOQ a series of dilutions of both nateglinide and metformin $\mathrm{HCl}$ was injected and plotted a calibration graph between peak areas and concentration. Finally, LOD and LOQ values were finalized using regression analysis.

The preferable formulas to calculate LOD and LOQ are as follows:

$$
\begin{aligned}
& \mathrm{LOD}=\frac{3.3 \times \sigma}{\mathrm{S}} \\
& \mathrm{LOQ}=\frac{10 \times \sigma}{\mathrm{S}}
\end{aligned}
$$

Where $\sigma=$ Standard deviation of the response and $S=$ Slope of calibration curve.

\section{Forced degradation studies}

Sample stock solution for forced degradation studies was prepared by mixing $62.1 \mathrm{mg}$ of sample powder with $70 \mathrm{ml}$ of diluent in $100 \mathrm{ml}$ volumetric flask and sonicated for $30 \mathrm{~min}$ and diluted to the mark with the same diluent.

\section{Acid-induced degradation}

Five milliliters of sample stock solution and $1 \mathrm{ml}$ of $1 \mathrm{~N} \mathrm{HCl}$ were taken in a $50 \mathrm{ml}$ volumetric flask, placed in water bath for $30 \mathrm{~min}$ at $60^{\circ} \mathrm{C}$ constant temperature. Further after cooling to room temperature, $1 \mathrm{ml}$ of $1 \mathrm{~N} \mathrm{NaOH}$ was added and diluted to the mark with diluent and stored at room temperature. The resulting solution was injected after $24 \mathrm{~h}$

\section{Alkali-induced degradation}

Five milliliters of sample stock solution and $1 \mathrm{ml}$ of $1 \mathrm{~N} \mathrm{NaOH}$ were taken in a $50 \mathrm{ml}$ volumetric flask, placed in water bath for $30 \mathrm{~min}$ at $60^{\circ} \mathrm{C}$

Table 1: Linearity results

\begin{tabular}{lll}
\hline Parameter & Nateglinide & Metformin $\mathbf{H C l}$ \\
\hline $\begin{array}{l}\text { Linearity and range } \\
(\mu \mathrm{g} / \mathrm{ml})\end{array}$ & $0.61-9.15$ & $7.5-75.15$ \\
Slope $(\mathrm{a})$ & 197,864 & \\
Intercept (b) & 458.32 & 50,772 \\
Coefficient correlation & 0.9998 & 47,812 \\
$\left(\mathrm{R}^{2}\right)$ & & 0.9991 \\
Regression equation & $\mathrm{y}=197,864 \mathrm{x}+458.32$ & $\mathrm{y}=50,772 \mathrm{x}+47,812$ \\
SD of intercept & $12,583.41$ & $74,355.68$ \\
\hline
\end{tabular}

SD: Standard deviation, $\mu \mathrm{g} / \mathrm{ml}$ : Microgram per milliliter constant temperature. Further after cooling to room temperature, $1 \mathrm{ml}$ of $1 \mathrm{~N} \mathrm{HCl}$ was added and diluted to the mark with diluent and stored at room temperature. The resulting solution was injected after $24 \mathrm{~h}$

\section{Peroxide-induced degradation}

Five milliliters of sample stock solution and $1 \mathrm{ml}$ of $30 \% \mathrm{H}_{2} \mathrm{O}_{2}$ were taken in a $50 \mathrm{ml}$ volumetric flask, placed in water bath for $30 \mathrm{~min}$ at $60^{\circ} \mathrm{C}$ constant temperature. Further after cooling to room temperature diluted to the mark with diluent and stored at room temperature. The resulting solution was injected after $24 \mathrm{~h}$.

\section{Thermal-induced degradation}

The sample powder was exposed at $105^{\circ} \mathrm{C}$ for $72 \mathrm{~h} .62 .1 \mathrm{mg}$ of this sample was weighed and transferred into $100 \mathrm{ml}$ volumetric flask containing $70 \mathrm{ml}$ of diluent and sonicated for $30 \mathrm{~min}$ and diluted to the mark with the same diluent. Further, $5 \mathrm{ml}$ was diluted to $50 \mathrm{ml}$ with diluent, stored at room temperature, and injected into RP-HPLC system after $24 \mathrm{~h}$.

\section{Photolytic degradation}

The sample powder was exposed under UV light for $24 \mathrm{~h}$. $62.1 \mathrm{mg}$ of this sample was weighed and transferred into $100 \mathrm{ml}$ volumetric flask containing $70 \mathrm{ml}$ of diluent and sonicated for $30 \mathrm{~min}$ and diluted to the mark with the same diluent. Further, $5 \mathrm{ml}$ was diluted to $50 \mathrm{ml}$ with diluent, stored at room temperature, and injected into RP-HPLC system after $24 \mathrm{~h}$.

\section{RESULTS AND DISCUSSION}

Selection of detection wavelength $\left(\lambda_{\max }\right)$

In the UV spectrum, nateglinide has shown $\lambda_{\max }$ at $212.3 \mathrm{~nm}$ and metformin $\mathrm{HCl}$ has shown $\lambda_{\text {max }}$ at $258.3 \mathrm{~nm}$. In the overlain spectra, both nateglinide and metformin $\mathrm{HCl}$ show absorbance at $221 \mathrm{~nm}$ as common middle wavelength (Fig. 3).

\section{Construction of calibration curve}

As shown in Figs. 4 and 5, straight lines are obtained on calibration plots with linearity and range from $0.61 \mu \mathrm{g} / \mathrm{ml}$ to $9.15 \mu \mathrm{g} / \mathrm{ml}$; whereas, the regression equation was $y=197,824 x+458.32$ for nateglinide and for metformin $\mathrm{HCl}$, the linearity and range from $7.5 \mu \mathrm{g} / \mathrm{ml}$ to $75.15 \mu \mathrm{g} / \mathrm{ml}$; whereas, the regression equation was $\mathrm{y}=50,772 \mathrm{x}+$ 47,812 . The $\mathrm{R}^{2}$ values for nateglinide and metformin $\mathrm{HCl}$ are 0.9998 and 0.9991, respectively (Table 1).

Analysis of nateglinide and metformin $\mathrm{HCl}$ from marketed tablets One of the marketed formulations was analyzed with the proposed RP-HPLC method and the mean assay was identified as $100.6 \%$ and $99.18 \%$ against the label claim of nateglinide $(60 \mathrm{mg}$ ) and metformin $\mathrm{HCl}(500 \mathrm{mg})$, respectively. The \%RSD of mean assay of the formulation was within the acceptable limits $\leq 2$ (Table 2).

\section{System suitability}

From the data obtained for six injections, it was observed that the resolution (Rs) was $>2$, tailing factor (Tf) was $<2$, USP theoretical plates

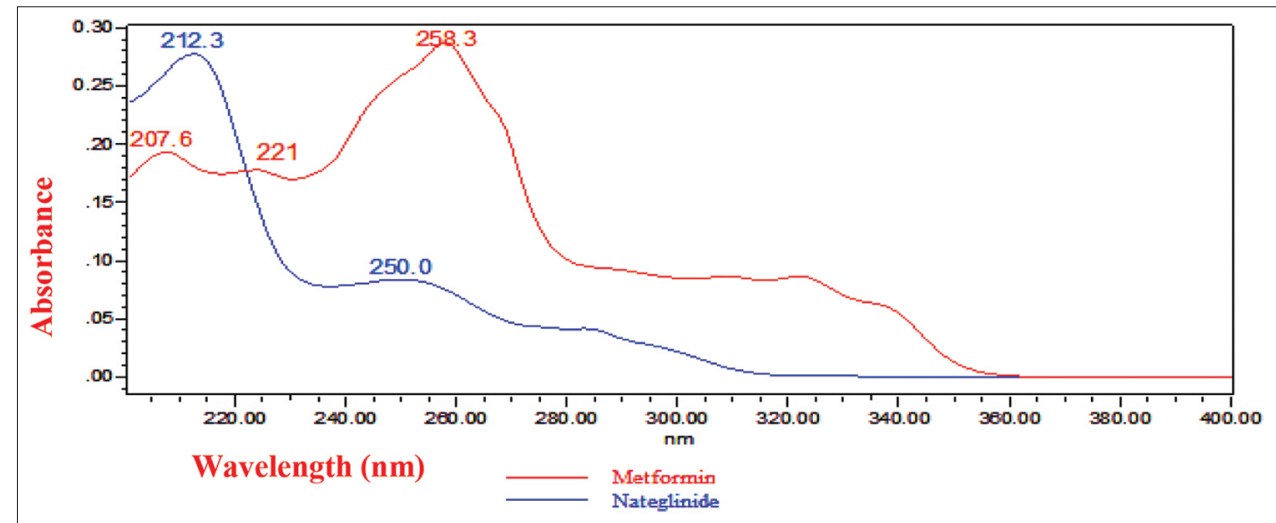

Fig. 3: Selection of isosbestic point for nateglinide and metformin $\mathrm{HCl}$ 
count (N) was $>2000$, and the \%RSD of peak areas of working standard solution was $<2$. The numerals are represented in Table 3 .

\section{Validation of proposed analytical method}

Selectivity and Specificity

From the chromatograms Fig. 6 on observation, it was found that the retention times and resolution of nateglinide and metformin $\mathrm{HCl}$ were

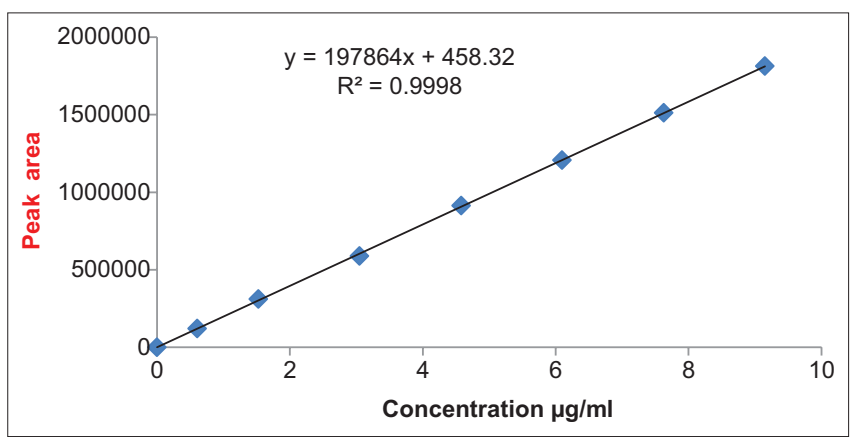

Fig. 4: Linearity curve of nateglinide

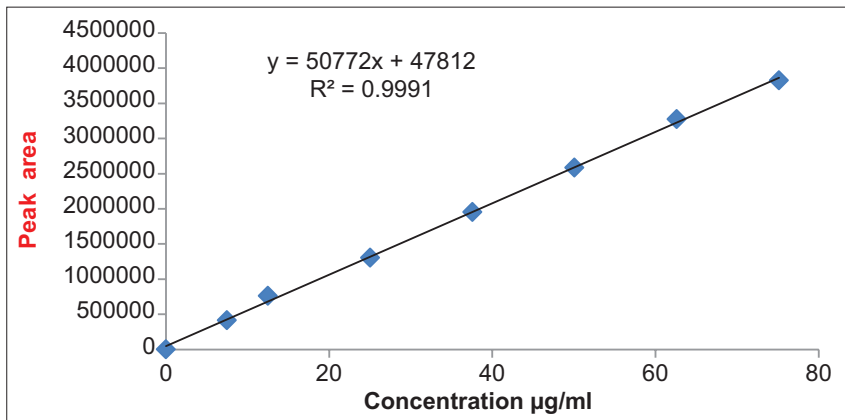

Fig. 5: Linearity curve of metformin $\mathrm{HCl}$ fixed same as such without any changes confirm the selectivity of the analytical method.

The perusal of Fig. 7 reveals that the mobile phase scan and placebo scan did not show any peaks at the retention time of analytes of interest. However, the tablet extracts scan and working standard solutions scan gave characteristic peaks of nateglinide and metformin $\mathrm{HCl}$. These results convey specificity of the method.

\section{Accuracy}

The calculated mean \% recoveries were $99.21 \%$ and $99.88 \%$ for metformin $\mathrm{HCl}$ and nateglinide, respectively. Hence, the recovery study proves the accuracy of the proposed RP-HPLC method (Table 4).

\section{Precision}

The \%RSD of peak areas of six replicate injections of working standard solution was estimated as $0.14 \%$ and $0.41 \%$ for metformin $\mathrm{HCl}$ and nateglinide, respectively. This indicates that the system precision was within the limits of acceptability.

The mean assay of six replicate injections of sample solutions was estimated as $99.53 \%$ for metformin $\mathrm{HCl}$ and $99.05 \%$ for nateglinide. Hence, the method was reproducible.

Six replicate injections of sample solutions when analyzed on different day by different analysts with different column and the mean assay was calculated as $99.65 \%$ for metformin $\mathrm{HCl}$ and $99.17 \%$ for nateglinide. Hence, the method was reproducible on different instrument on different day (Table 5).

\section{Robustness}

To ensure the robustness of the proposed method, sample solutions were injected for 3 times after each change in optimized chromatographic parameters. From the procured data, mean peak area of sample, \%RSD of peak area, and mean assay for sample were calculated. The \%RSD of sample peak areas at all the deliberate conditions was identified as $\leq 2 \%$ (Table 6).

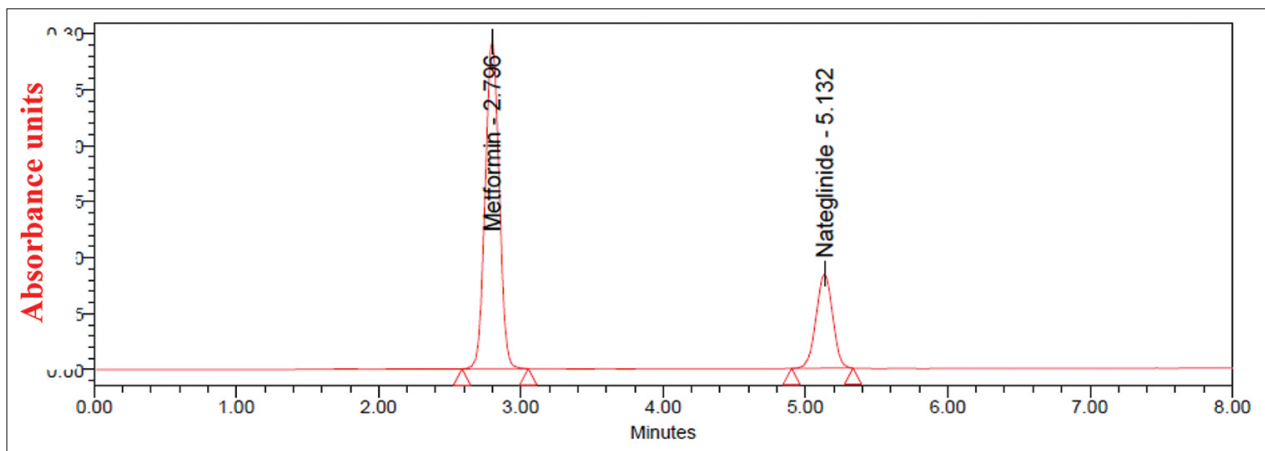

Fig. 6: Chromatogram of mixture of standard nateglinide and metformin $\mathrm{HCl}$ with retention time of $2.796 \mathrm{~min}$ and $5.132 \mathrm{~min}$, respectively Table 2: Analysis of nateglinide and metformin $\mathrm{HCl}$ from marketed tablets

\begin{tabular}{llllll}
\hline Brand name & Drugs & Label claim & Assay* & Amount recovered & Amount recovered \pm \%RSD \\
\hline GLINATE-MF & Nateglinide & $60 \mathrm{mg}$ & $99.18 \%$ & $59.51 \mathrm{mg}$ & $59.51 \pm 0.61$ \\
& Metformin $\mathrm{HCl}$ & $500 \mathrm{mg}$ & $100.60 \%$ & $503 \mathrm{mg}$ & $503 \pm 0.82$ \\
\hline
\end{tabular}

*Average of five determinations, RSD: Relative standard deviation

Table 3: System suitability results

\begin{tabular}{|c|c|c|c|c|}
\hline \multirow[t]{2}{*}{ Parameter } & \multicolumn{2}{|l|}{ Observed results* } & \multicolumn{2}{|l|}{$\%$ RSD } \\
\hline & Metformin $\mathrm{HCl}$ & Nateglinide & Metformin $\mathrm{HCl}$ & Nateglinide \\
\hline Retention time (Rt) & $2.79 \pm 0.00$ & $5.11 \pm 0.00$ & 0.093 & 0.068 \\
\hline Theoretical plates $(\mathrm{N})$ & $3557 \pm 34.28$ & $8841.67 \pm 52.27$ & 0.964 & 0.591 \\
\hline Tailing factor (Tf) & $0.87 \pm 0.11$ & $0.95 \pm 0.024$ & - & - \\
\hline Resolution (Rs) & - & $11.28 \pm 0.15$ & - & 1.38 \\
\hline
\end{tabular}

${ }^{*}$ Average of six determinations, Rt: Retention time, Rs: Resolution, USP: United States Pharmacopeia, Tf: Tailing factor. RSD: Relative standard deviation 


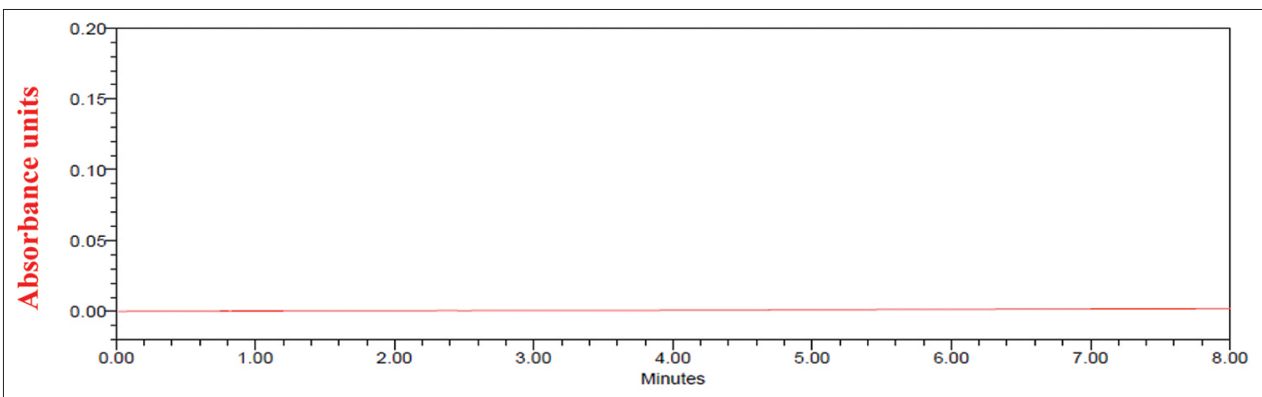

Fig. 7: Chromatogram of placebo

Table 4: Accuracy results

\begin{tabular}{llllll}
\hline Drugs & Level $\%$ & Amount added $(\boldsymbol{\mu g} / \mathbf{m l})$ & Amount found $(\boldsymbol{\mu g} / \mathbf{m l})$ & \%Recovery \pm SD $(\mathbf{n}=\mathbf{3})$ & \%RSD \\
\hline Metformin $\mathrm{HCl}$ & 50 & 25.1 & 24.78 & $98.73 \pm 0.3$ & 0.30 \\
& 100 & 50.1 & 49.99 & $99.73 \pm 0.25$ & 0.25 \\
& 150 & 75.1 & 74.50 & $100 \pm 0.94$ & 0.94 \\
Nateglinide & 50 & 3.1 & 3.13 & $99.53 \pm 0.15$ & 0.79 \\
& 100 & 6.2 & 6.17 & $100.1 \pm 0.43$ & 0.15 \\
& 150 & 9.2 & 9.24 & 0.429 \\
\hline
\end{tabular}

STD: Standard, SD: Standard deviation RSD: Relative standard deviation

Table 5: Precision results

\begin{tabular}{|c|c|c|c|}
\hline Parameter & Drug & Mean peak area* & $\%$ RSD \\
\hline \multirow[t]{3}{*}{ System precision } & Metformin $\mathrm{HCl}$ & $2,517,052 \pm 3624.25$ & 0.14 \\
\hline & Nateglinide & $1,199,129 \pm 4929.91$ & 0.41 \\
\hline & & Mean \% recovery* & \\
\hline \multirow[t]{2}{*}{ Method precision } & Metformin $\mathrm{HCl}$ & $99.53 \pm 0.35$ & 0.35 \\
\hline & Nateglinide & $99.05 \pm 0.63$ & 0.63 \\
\hline \multirow{5}{*}{ Intermediate precision } & Metformin $\mathrm{HCl}$ & Mean \% recovery* & \\
\hline & Analyst- 1 & $99.53 \pm 0.35$ & 0.35 \\
\hline & Nateglinide & Mean \% recovery* & \\
\hline & Analyst-1 & $99.05 \pm 0.63$ & 0.39 \\
\hline & Analyst 2 & $99.17 \pm 0.4$ & 0.41 \\
\hline
\end{tabular}

*Average of six determinations, SD: Standard deviation, \%RSD: Percentage relative standard deviation

Table 6: Robustness results

\begin{tabular}{|c|c|c|c|c|c|c|}
\hline \multirow[t]{2}{*}{ Parameter } & \multicolumn{3}{|c|}{ Metformin HCl } & \multicolumn{3}{|c|}{ Nateglinide } \\
\hline & Area* & $\mathbf{R} \mathbf{t}^{*}$ & $\mathbf{T f}^{*}$ & Area* & $\mathbf{R t}^{*}$ & Tf* \\
\hline Flow plus (1.2 ml/min) & $2,266,340$ & 2.31 & 1.04 & $1,046,318$ & 4.23 & 1.01 \\
\hline Organic solvent ratio $(+10 \%)$ & $2,262,110$ & 2.45 & 1.04 & $1,153,106$ & 3.84 & 1.01 \\
\hline Organic solvent ratio $(-10 \%)$ & $2,753,249$ & 3.25 & 1.05 & $1,348,965$ & 7.36 & 0.98 \\
\hline
\end{tabular}

*Average of three determinations, Rt: Retention time, Tf: Tailing factor

\section{Table 7: LOD and LOQ results}

\begin{tabular}{llll}
\hline S. No. & Parameter & Nateglinide & Metformin HCl \\
\hline 1 & LOD & $0.21 \mu \mathrm{g} / \mathrm{ml}$ & $4.8 \mu \mathrm{g} / \mathrm{ml}$ \\
2 & LOQ & $0.63 \mu \mathrm{g} / \mathrm{ml}$ & $14.6 \mu \mathrm{g} / \mathrm{ml}$ \\
\hline
\end{tabular}

LOD: Limit of detection, LOQ: Limit of quantification

Flow rate $1.2 \mathrm{ml}$

The sample assay at $1.2 \mathrm{ml} / \mathrm{min}$ was calculated as $99.87 \%$ for nateglinide, and for metformin $\mathrm{HCl}$, it was $99.83 \%$.

Flow rate $0.8 \mathrm{ml}$

The sample assay at $0.8 \mathrm{ml} / \mathrm{min}$ was calculated as $99.53 \%$ for nateglinide, and for metformin $\mathrm{HCl}$, it was $99.83 \%$.

\section{More organic mobile phase $\mathbf{( + 1 0 \% )}$}

The mobile phase organic composition when changed to $+10 \%$ the calculated assay was $98.8 \%$ for nateglinide, and for metformin $\mathrm{HCl}$, it was $99.07 \%$.

\section{Less organic mobile phase $\mathbf{( - 1 0 \% )}$}

The mobile phase organic composition when changed to $+10 \%$ the calculated assay was $99.67 \%$ for nateglinide, and for metformin $\mathrm{HCl}$, it was $99.73 \%$.

\section{LOD and LOQ}

SD of intercept was calculated by regression analysis. Using slope of calibration plot and SD of intercept, LOQ and LOD are calculated.

The estimated LOD and LOQ values for nateglinide are $0.21 \mu \mathrm{g} / \mathrm{ml}$ and $0.63 \mu \mathrm{g} / \mathrm{ml}$, respectively; for metformin $\mathrm{HCl}$, the LOD and LOQ are $4.8 \mu \mathrm{g} / \mathrm{ml}$ and $14.6 \mu \mathrm{g} / \mathrm{ml}$, respectively (Table 7). 
Table 8: Stability indicating method data for nateglinide and metformin $\mathrm{HCl}$

\begin{tabular}{|c|c|c|c|c|}
\hline \multirow[t]{2}{*}{ Degradation condition } & \multicolumn{2}{|c|}{ Nateglinide } & \multicolumn{2}{|c|}{ Metformin HCl } \\
\hline & Peak area & $\%$ degradation & Peak area & $\%$ degradation \\
\hline Control & $1,202,125$ & -0.1 & $2,523,178$ & -0.1 \\
\hline $1 \mathrm{~N} \mathrm{NaOH}$ (alkaline) & 994,732 & 17.2 & $2,139,878$ & 15.2 \\
\hline $30 \% \mathrm{H}_{2} \mathrm{O}_{2}$ (peroxide) & 105,7824 & 12 & $2,128,941$ & 15.6 \\
\hline Thermal $\left(105^{\circ} \mathrm{C}\right)$ & 994,712 & 17.2 & $2,091,462$ & 17.1 \\
\hline Photolytic & 988,793 & 17.7 & $2,082,987$ & 17.5 \\
\hline
\end{tabular}

$\mathrm{N}$ : Normality, $\mathrm{HCl}$ : Hydrochloric acid, $\mathrm{NaOH}$ : Sodium hydroxide, $\mathrm{H}_{2} \mathrm{O}_{2}$ : Hydrogen peroxide

\section{Forced degradation studies}

Estimated assay after forced degradation with $1 \mathrm{~N} \mathrm{HCl}$ was $85.3 \%$ and $85.3 \%$ of nateglinide and metformin $\mathrm{HCl}$, respectively, it was $82.9 \%$ and $84.3 \%$ of nateglinide and metformin $\mathrm{HCl}$, respectively, with $1 \mathrm{~N}$ $\mathrm{NaOH}$, and with peroxide, it was $88.1 \%$ and $84.5 \%$ of nateglinide and metformin $\mathrm{HCl}$, respectively. When the sample was exposed at $105^{\circ} \mathrm{C}$, the estimated assay was $82.9 \%$ and $83.0 \%$ of nateglinide and metformin $\mathrm{HCl}$, respectively, and sample on exposure with UV radiation the assay was $82.4 \%$ and $82.6 \%$ of nateglinide and metformin $\mathrm{HCl}$, respectively (Table 8).

\section{CONCLUSION}

From the available literature, it was observed and notified that only few articles are reported the stability indicating simultaneous estimations of nateglinide and metformin $\mathrm{HCl}$ by RP-HPLC. A New stability indicating method was developed and fully validated with mobile phase (acetonitrile:0.1\% orthophosphoric acid 30:70 v/v), column (luna phenyl hexyl $150 \mathrm{~mm} \times 4.6 \mathrm{~mm}, 3.5 \mu$ ), detection wavelength at $221 \mathrm{~nm}$, and at other optimized chromatographic conditions. From the validation report, it was found that the developed RP-HPLC method was suitable, simple, economic, specific, and precise for the estimation of nateglinide and metformin $\mathrm{HCl}$ in tablet dosage forms. Stability studies indicated that the nateglinide and metformin $\mathrm{HCl}$ could be evaluated simultaneously by RP-HPLC in the presence of their degradation products. Hence, this method can be applied and implemented to study stability samples in the industry.

\section{ACKNOWLEDGMENT}

The authors are thankful to Care Labs for their technical support in finishing this research work.

\section{AUTHORS' CONTRIBUTIONS}

K Md Ismail: Concept and design of work, data collection, data analysis, drafting and revision of article, and final approval of the revision to be published.

Dr. A. Lakshmana Rao: Design of work, drafting and revision of article, and final approval of the revision to be published.

\section{CONFLICTS OF INTEREST}

The authors declare that there are no conflicts of interest.

\section{AUTHORS' FUNDING}

Nil.

\section{REFERENCES}

1. Hirschberg Y, Karara AH, Pietri AO, McLeod JF. Improved control of mealtime glucose excursions with coadministration of nateglinide and metformin. Diabetes Care 2000;23:349-53.

2. Horton ES, Clinkingbeard C, Gatlin M, Foley J, Mallows S, Shen S. Nateglinide alone and in combination with metformin improves glycemic control by reducing mealtime glucose levels in Type 2 diabetes. Diabetes Care 2000;23:1660-5.
3. Geetha P, Sundharam PS. Drug utilization evaluation of antidiabetic drugs among Type 2 diabetes patients of Tamil Nadu. Asian J Pharm Clin Res 2017;10:202-5.

4. Muhas C, Naseef PP. A review article-gestational diabetes mellitus. Int J Curr Pharm Res 2017;9:1-5.

5. Natasya A, Andrajati R, Sauriasari R. Cross-sectional study of association between glycemic control and quality of life among diabetic patients. Int J App Pharm 2018;10:92-6.

6. Dhodi JB, Mestry SN, Juvekar AR. Diabetic nephropathy-genesis, prevention, and treatment. Int J Pharm Pharm Sci 2014;6:42-7.

7. Thomas A, Patil S, Nanda R, Kothapalli L, Deshpande A. Stabilityindicating RP-HPLC method for determination of metformin hydrochloride and nateglinide in bulk and tablet formulations. Curr Pharm Anal 2012;8:381-8.

8. Chengalva P, Parameswari SA, Aruna G. Development and validation of RP-HPLC method for metformin hydrochloride and nateglinide in bulk and combined dosage form. Int J Pharm Pharm Sci 2016;8:267-71.

9. El-Zaher AA, Elkady EF, Elwy HM, Saleh MA. A new rapid and economic liquid chromatographic method for simultaneous determination of meglitinides with metformin: Application in the presence of metformin and repaglinide impurities and related compounds. J Iran Chem Soc 2018;15:61-74.

10. Haranadha R, Chunduri B, Dannana GS. Development and validation of LC-MS/MS method for simultaneous quantification of metformin HCL and nateglinide in human plasma and its application to a pharmacokinetic study. World J Pharm Pharm Sci 2016;5:651-67.

11. Ramanjireddy T, Duraiswamy D, Kothapalli C. Method development and validation of Metformin and repaglinide in rabbit plasma by RPHPLC. Fabad J Pharm Sci 2012;35:69-75.

12. Patel JR, Suhagia BN, Patel BH. Simultaneous spectrophotometric estimation of metformin and repaglinide in a synthetic mixture. Indian J Pharm Sci 2007;69:844-6.

13. Thomas AB, Patil SD, Kothapalli LP, Nanda RK, Bhosle SS, Deshpande AD. Estimation of nateglinide and metformin hydrochloride in tablet dosage form by spectrophotometric methods. J Pharm Res 2011; 10:102-5

14. Soni LK, Narsinghani T, Jain M. Development and validation of RPHPLC method for simultaneous estimation of metformin hydrochloride and repaglinide in tablet dosage form. J Liq Chromatogr Relat Technol 2012;35:385-92.

15. Aslan SS, Yilmaz B. Derivative spectrophotometric and isocratic high performance liquid chromatographic methods for simultaneous determination of repaglinide and metformin hydrochloride in pharmaceutical preparations. Am J Anal Chem 2017;8:541-52.

16. Fouad M, Rashed NS. Development and validation of chromatographic and spectroscopic methods for estimation of repaglinide and metformin HCL in combined dosage form. J Glob Trends Pharm Sci J 2014;5:1844-8.

17. Sheth KB, Sagar GV. Development and validation of RP-HPLC method for simultaneous estimation of metformin hydrochloride and mitiglinide calcium dihydrate in combined dosage form. Pharm Sci Monit 2012;3:2681-93

18. Elkady EF, El-Zaher AA, Elwy HH, Saleh MA. Validated liquid chromatographic method for simultaneous determination of Metformin, pioglitazone, sitagliptin, repaglinide, glibenclamide and gliclazide-application for counterfeit drug analysis. J Anal Bioanal Tech 2015;S13:1-8.

19. El-Wasseef DR. Simultaneous determination of metformin, nateglinide and gliclazide in pharmaceutical preparations using micellar liquid chromatography. Int J Biomed Sci 2012;8:144-51.

20. Thomas AB, Patil SD, Nanda RK, Kothapalli LP, Bhosle SS, Deshpande AD. Stability-indicating HPTLC method for simultaneous determination of nateglinide and metformin hydrochloride in 
pharmaceutical dosage form. Saudi Pharm J 2011;19:221-31

21. Ahir KB, Patelia EM, Shah A. Simultaneous estimation of metformin hydrochloride and repaglinide in pharmaceutical formulation by HPTLC-densitometry method. J Chromatogr Sep Tech 2013;4:1-5.

22. Skoog DA, West DM, Holler FJ, Crounch S. Fundamentals of Analytical Chemistry. $8^{\text {th }}$ ed. London: Thomson Asia Pvt Ltd.; 2004. p. 160-7, 971-95.

23. Ahuja S, Dong M, editors. Handbook of Pharmaceutical Analysis by HPLC. Vol. 6. Amsterdam, Boston: Elsevier Academic Press; 2005. p.
19-44, 47-69, 197-210.

24. Snyder L, Kirkland JJ, Glajch JL. Practical HPLC Method Development. $2^{\text {nd }}$ ed. Hoboken, New Jersey: John Wiley and Sons Inc.; 1997. p. 1-542.

25. International Council for Harmonisation of Technical Requirements for Pharmaceuticals for Human Use. International Conference on Harmonization of Technical Requirements for Registration of Pharmaceuticals for Human Use. Validation of Analytical ProceduresText and Methodology; ICH Q2 (R1); 2005. 